\title{
基礎疾患下での虚血障害と薬物の効果
}

\section{樋ロマキア ${ }^{1)}$, 梅村 和夫 ${ }^{2)}$}

近年, 老齢化社会を迎え, 糖尿病, 高血圧, 高脂血症, 動脈硬化などの基礎疾患を持った高㱓者が増加している. これらの基礎疾患下では, わずかな変化でも臓器や組織 が虚血に陥りやすく, 更に, 虚血時の代謝異常や生理活 性物質に対する感受性・反応性の変化による微小循環障 害などにより，虚血障害が六進することが考えられる. 薬理学的研究上, 最終的には病態下での検討が重要となっ てくる. また, 血流の完全途絶の状態より, その周辺部 あるいはその前段階の低流量灌流状態が病態の進展の上 からも薬物療法上からも重要だと思われる. 不完全虚血 時の臓器局所循環調節は, 臟器特異性があり, またいろ いろな因子が複雑に関連しているので, 少なくとも臓器, 最終的には生体位での検討が必要となる.

本シンポジウムでは，1）虚血：不完全虚血，2）生 体位または摘出臓器，3）基礎疾患（全身性の疾患）: 糖尿病, 高脂血症, 高血圧症, 動脈硬化症, 4) 薬物の 効果, という 4 つのキーワードのもとに下記の 6 つの 講演を行った. これらの基礎疾患が不在又は存在する個 体の心臓・腎臓・下肢・脳といった各種臓器における虚 血時の循環・代謝の臟器特異性と低灌流障害, そしてこ れらに対する薬物の効果について基礎および臨床面より 質疑討論を行った. 主要臓器の虚血に関し, 糖尿病心臓 の虚血障害と薬物の効果について樋ロマキュが, 心蔵と 腎臓の微小循環について開発した針プローブ型生体顕微 鏡を用い梶谷文彦が, 末梢循環障害については長年糖尿 病壊疽の治療 - 研究をしている島田孝夫が, 循環器全般 の虚血に関し脂質代謝異常の面より田中孝生が, 脳虚血 に関しては抗酸化等の有害物質除去の面より田中淳二が, 凝固・線溶系等を含め主に血流改善の面から梅村和夫が 各々講演を行った.

1. 基調講演 : 基礎疾患と不完全虚血; 臓器障害および 薬物効果の差異 (樋口マキュ : 琉球大・医・薬理).

まず, 上半身肥満, 耐糖能異常, 高中性脂肪血症, 高
血圧および動脈硬化等の基礎疾患下では, 代謝異常や有 害物質の産生がみられ，お互い悪影響を及ぼしながら， 最終的には, 血管内腔の狭窄, 血栓形成傾向, NO 産生 能低下，血管平滑筋収縮傾向，心肥大などで組織の血流 予備能は低下し，虚血傾向へと進む展開を示した．組織 に流入する血液量と流出量とは同じとしても, その微小 循環に血液が流れてこそ, 有効な血流となるわけで, 細 小動脈硬化や内皮細胞障害, 自律神経の変性等があると, 必要な時に有効血流が得にくい状態になると考えられる. 実際, 基礎疾患下の臟器は虚血に陥り易く, 且つ虚血障 害を受け易いのか？臟器特異性があるのか? 生理活性物 質に対する反応性は量的に異なってくるのか？これらを 考慮して動物実験および臨床結果より不完全虚血の話を 進めた，虚血臟器への対策として，可逆的障害の間に有 効血流量を増し酸素を供給し, 有害産生物を除去し, エ ネルギー消費量を減少させる等がある．薬物による虚血 の制御の上で重要と思われる, 生体において虚血時産生 され，保護的にまたは増覀的に作用する生理活性物質 (アデノシン, 熱ショックタンパク, アンジオテンシン IIや神経伝達物質等）の一部を紹介した.

次に, 実験糖尿病心臓において, 低灌流下の薬物効果 が顕著に変化してくることに注目を促した．1）生体位 心臓と同様に摘出灌流心臓で屯, 冠流量減少に依存した 心筋障害には部位特異性があり, 左心室外膜下層心筋よ り内層心筋で顕著である. 虚血時の心筋エネルギー代謝 異常に対する薬物の効果は, 少なくとも臓器での検討が 必要であり，またその全身循環動態に対する作用を反映 するので, 最終的には生体位の実験が求められることを 示した．2）基礎疾患として糖尿病があると，非糖尿病 心臟では心筋梗塞を起こさない程度の軽度の心筋虚血に よってあ容易に重い心機能不全がもたらされ，薬物に対 する反応も変化してくることを示した(1). 即ち, (1)糖 尿病心臓の方が低灌流障害を受け易いが，低灌流初期に 
は高濃度蓄積されたグリコーゲンが利用され虚血障害防 止に働く故, その障害の程度は, 低灌流の程度や時間お よび糖尿病の重症度で異なる. (2)両心臟で虚血時の左心 室ステフネス増加は内層心筋の ATP 減少とょく相関し ているが, 糖尿病心蔵の方が軽度の ATP 減少で容易に ステフネスは増加し相関曲線は一致しない。非糖尿病と 糖尿病心臓間で障害度を比較評価する場合, 単純に心筋 細胞内総 ATP 量で判断出来ないことを示し, 糖尿病心 臓の細胞内 ATP 分画や $\mathrm{Ca}^{2+}$ 恒常性変動に関する研究 の必要性を提示した。 (3)糖尿病心臓では, $\beta_{1}$-アドレナ リン受容体を介する反応は低下しているが，この受容体 を介し虚血障害は増悪される。 また, 低灌流下の $\mathrm{K}_{\mathrm{ATP}}$ チャネル開口による心筋保護効果は, 非糖尿病心蔵の方 が感受性が高くその寄与度む大きいことを示した.

2. 心臓・腎臟における微小循環の in vivo 可視化 (暒谷文彦 : 川崎医大・医用工学).

まず，ブ夕生体位心臓を用いて，心内膜側の血流と心 外膜側の血流は全く異なるという拍動時の冠循環の特徵 を示した(2). 心筋収縮により外側では小静脈内径のみ 大きくなり, 小動脈内径には変化なく心周期を通しほぼ 血流は順流であるが, 内側の冠細小動・静脈内径は共に 約 20\%減少し且つ細動脈においては収縮期を通して逆 流がみられる，冠狭窄による灌流圧低下により拡張期の 血流は減少し収縮期の逆流は増し, 冠血流減少は内層の 方が顕著で虚血に陥り易いことを示した，反応性充血よ りみた血管反応性は内層の方がよく，その拡張反応の差 には NO が関与する. 即ち $100 \mu$ 以上の血管の拡張は外 層ではほとんど見られず，見かけ上の血管予備能はむし ろ外層で大きいことが示唆された。 ニトログリセリン冠 動脈内投与は $100 \mu$ 以上の血管を主に拡張するが， 100 $\mu$ 以下の血管も一時的に拡張させる. 次に腎臓の微小循 環について，表面と深部のネフロンでは，また輸入と輸 出動脈ではアデノシン等の薬物に対する感受性に相違が あることを示した．腎微小血管の解析度に関する質問， また，局所の心筋収縮力低下によるバルジング部の心内 膜側の血管径はどの様に変わるかという，心機能と冠血 管変形の関係について, 会場と興味ある活発な討論がな された.

3. 基礎疾患下の微小循環障害と薬物の作用（島田 孝夫 : 慈恵会医大・内科 3$)$.

糖尿病性下肢壊疽について臨床デー夕を示し, 末梢循 環状態と薬物の効果をよく把握できる方法および薬物療 法について講演した(3). (1)Lipo プロスタグランジン (PG) $\mathrm{E}_{1}$ は糖尿病で障害されやすい細動脈レベルの血
管に作用する．(2)PGE 1 は短期大量療法ではシャント血 流を増加させるが，長期間投与することにより自律神経 機能を改善させる. (3)Lipo $\mathrm{PGE}_{1}$ と経口 $\mathrm{PGI}_{2}$ を比較 すると, 軽症例には経口 $\mathrm{PGI}_{2}$ がよく, Lipo $\mathrm{PGE}_{1}$ は重 症例ほど有効であった. (4)シロスタゾールは細動脈より 末梢の血管に作用する. (5)糖尿病性末梢循環障害に対す る $\alpha$ 刺激薬の有効性が示唆された. 末梢循環障害におけ る抗血小板療法をこの検查方法はどう捉えるのかという 質問があった.

4. 虚血時の FABP (fatty acid binding protein) の 役割（田中孝生 : 大阪医大・内科 3).

長鎖脂肪酸を特異的に結合しその輸送・利用に関与し ている, 細胞内, 特に心筋細胞内に多量に存在する, 低 分子量で水溶性の藏器特異性のタンパク (FABP) につ いて講演した。この FABP は, 虚血時に増加し細胞機 能を障害する長鎖脂肪酸中間代謝産物も結合し，これら の有害作用を緩衝するし, 不完全虚血や虚血再灌流時に 発生する活性酸素の消去系としても働くと考えられてい る。また，心筋梗塞時クレアチンホスホキナーゼ (CPK) より早期に血中や尿中に排泄され，心筋傷害の 特異的マーカーとなり, 超早期の診断と治療を可能にす る(4). その逸脱量より, 再灌流療法や梗塞サイズの推 定への応用が期待された。 心筋梗塞前段階の軽度の心筋 傷害状態でも逸脱してくる可能性が示され, 虚血心筋保 護作用との兼称合いはまだ不明である．FABP の逸脱 量と細胞機能障害との関係について質問があったが，基 礎疾患下での FABP の役割についてと同様, 今後の課 題とされた.

5. 脳虚血障害と薬物による組織保護（田中淳二 : 第一 製薬・東京 R\&D センター).

まず，動物実験脳虚血モデルにおいて，脳虚血時の梗 塞拡大を抗酸化作用を持つ薬物, エブセブレンが改善す ることより, 脳虚血障害におけるフリーラジカルの関与 を示唆した(5). 次に, 脳虚血時のリン酸化タンパク質 の変化について述べた．加齢によるリン酸化タンパク質 の変化が知られているが, 脳虚血一再灌流時にはその恒 常性は保たれていることを示した. フリーラジカルの検 出方法による相違点抢よびフリーラジカルの産生はどの 時点でみられるかとの質問があり, 再灌流障害に対する フリーラジカルの関与は大きいが，不完全虚血時でも産 生はみられるとの討議があった。

6. 脳梗塞進展に関わる因子（梅村和夫：浜松医大・薬 理).

光増感反応を利用した血管内皮傷害による血栓形成法 
を中大脳動脈に応用した。 その血栓モデルを用いて, 脳 梗塞の進展に対し, 血小板の大きな関与を示唆した(6). 深部組織 $\mathrm{O}_{2}$ 分圧測定より, 薬物による早期の血流再開 の重要性を示した. 自然発症高血圧ラット (SHR)では, 脳虚血時において血流保持能の低下やグルタミン酸放出 の穴進がみられ, 脳梗塞面積はより拡大する. 興奮性ア ミノ酸受容体のうち NMDA 受容体は虚血直後に, AMPA 受容体は長期にわたり神経細胞障害に寄与して いることを示した. 脳梗塞の進展に, 虚血周辺部での OH-ラジカルも関与していることが示唆された. 血圧上 昇前の SHR や脳卒中易発症性 SHR (SHRSP) におけ る脳梗塞の進展について，また脳にはリスク領域とか側 副血行路はあるのかの質疑があった. 血流と細胞保護作 用の関係は更なる検討を要すると締めくくった.

\section{文献}

1) Higuchi M, Miyagi K, Nakasone J and Sakanashi M: Role of high glycogen in underperfused diabetic rat hearts with added norepinephrine. J Cardiovasc Pharmacol 26, 899-907 (1995)

2) Yada $T$, Hiramatsu O, Kimura A, Goto M, Ogasawara Y, Tsujioka K, Yamamori S, Ohno K,
Hosaka $\mathrm{H}$ and Kajiya $\mathrm{F}$ : In vivo observation of subendocardial microvessels of the beating porcine heart using a needle-probe video-microscope with a CCD camera. Circ Res 72, 939-946 (1993)

3) Shimada T, Isogai $Y$, Suzuki $H$ and Kawakami K: Using nuclear medicine and ultrasonography to study the acting site of lipo PGE1 in peripheral artery disease. 脈管学 34, 449-454 (1994)

4) Sohmiya K, Tanaka T, Tsuji R, Yoshimoto K, Nakayama Y, Hirota Y, Kawamura K, Matsunaga Y, Nishimura S and Miyazaki H: Plasma and urinary heart-type cytoplasmic fatty acid-binding protein in coronary occlusion and reperfusion induced myocardial injury model. J Mol Cell Cardiol 25, 1413-1426 (1993)

5) Tanaka J and Yamada F: Ebselen (PZ-51) inhibits the formation of ischemic brain edema. In Selenium in Biology and Medicine, Edited by Wendel A, pp165-168, Springer-Verlag, Heidelberg (1989)

6) Umemura K, Wada $K$, Uematsu $T$ and Nakashima M: Evaluation of the combination of tissue type plasminogen activator, SUN9216, and a thromboxane A2 receptor antagonist, vapiprost in rat middle cerebral artery thrombosis model. Stroke 24, 1077-1081 (1993) 